\title{
A Study of Gene Expression in the Nematode Resistant Wild Peanut Relative, Arachis stenosperma, in Response to Challenge with Meloidogyne arenaria
}

\author{
Patricia Messenberg Guimarães • Ana Cristina Miranda Brasileiro • Karina Proite • \\ Ana Claudia Guerra de Araújo • Soraya Cristina Macedo Leal-Bertioli • \\ Aline Pic-Taylor • Felipe Rodrigues da Silva • Carolina Vianna Morgante • \\ Simone da Graça Ribeiro • David John Bertioli
}

Received: 26 April 2010 /Accepted: 27 August 2010/Published online: 14 September 2010

(C) Springer Science+Business Media, LLC 2010

\begin{abstract}
Peanut (Arachis hypogaea) is amongst the most important legume crops in the world. One of its main yield constraints is the root-knot nematode Meloidogyne arenaria. A number of wild Arachis species, including $A$. stenosperma, are resistant to nematodes, and are a potential source of new resistance alleles for cultivated peanut. Using in silico subtraction of ESTs and macroarray analysis, we identified genes differentially expressed in A. stenosperma roots during its resistance response to $M$. arenaria. The three most differentially expressed genes [Auxin Repressed Protein (AsARP), Cytokinin Oxidase (AsCKX) and Metallothionein Type 2 (AsMET2)] were further analyzed using northern-blot and showed distinct expression profiles in the
\end{abstract}

Communicated by: John Manners

Electronic supplementary material The online version of this article (doi:10.1007/s12042-010-9056-z) contains supplementary material, which is available to authorized users.

P. M. Guimarães $(\bowtie) \cdot$ A. C. M. Brasileiro • A. C. G. de Araújo ·

S. C. M. Leal-Bertioli • F. R. da Silva • C. V. Morgante •

S. d. Ribeiro

EMBRAPA Recursos Genéticos e Biotecnologia,

Parque Estação Biológica,

CP 02372, Final W5 Norte,

Brasília, DF, Brazil

e-mail: messenbe@cenargen.embrapa.br

K. Proite $\cdot$ A. Pic-Taylor $\cdot$ D. J. Bertioli

Universidade de Brasília,

Campus I,

Brasília, DF, Brazil

D. J. Bertioli

Universidade Católica de Brasília,

Campus II, 916 Norte,

Brasília, DF, Brazil resistant $A$. stenosperma and susceptible $A$. hypogaea, both after, and sometimes even before, challenge with nematodes. Of the three most differentially expressed genes, AsARP and AsCKX are potentially involved in plant hormonal balance, and AsMET2 may be related to the reactive oxygen reaction triggered by the hypersensitive response (HR).

Keywords Meloidogyne arenaria $\cdot$ Peanut $\cdot$ Root-knot nematode $\cdot$ Resistance genes

\section{Introduction}

Legumes are an important source of protein for humans and livestock. Peanut (Arachis hypogaea) is amongst the most important legumes in the world, with a global production of 48 million tons and a key role in food security in Africa and Asia (Wittwer 1981; FAOSTAT 2006). Worldwide, the major constraints to peanut production are foliar fungi, nematodes and drought (Starr et al. 2002; Luo et al. 2005a).

The peanut root-knot nematode, Meloidogyne arenaria, causes substantial yield losses, reduction in pod and seed quality, stunted plant growth and premature plant death (Starr et al. 2002). Management of root-knot disease is costly, and difficult, with the use of nematicides hindered by human toxicological effects and environmental issues (Dickson and Waele 2005).

Resistance to the peanut root-knot nematode was not available until 1999, when the cultivars COAN and NemaTAM with resistance to $M$. arenaria and $M$. javanica were released (Simpson 2001; Simpson et al. 2003). The resistance of both cultivars is based on the same alien 
interstitial chromosomal segment from $A$. cardenasii. The chromosomal segment suffers almost complete suppression of recombination and spans one-third to one-half of a linkage group (Nagy et al. 2010). The identification of alternative sources of resistance would be desirable since the continued planting of cultivars with the same genes of resistance may lead to the development of virulent nematode populations, as has occurred with $M$. incognita where populations virulent to tomato varieties harboring the Mi resistance gene have arisen (Kaloshian et al. 1996). In addition, it seems likely that wild alleles in the $A$. cardenasii chromosomal segment are detrimental to yield since both resistant cultivars yield lower than similar susceptible ones in the absence of disease pressure (Church et al. 2000; Starr et al. 2002). This provides an additional incentive for the characterization of new resistance sources, since they may have lower linkage drag with agronomically unfavorable alleles.

The wild relatives of peanut are a rich source of disease resistance genes, because they have high genetic diversity and have been selected during evolution in a range of environments and biotic stresses (Stalker 1997; Leal-Bertioli et al. 2007). In this study, the AA genome $A$. stenosperma (accession V10309) was used because: it is resistant to $M$. arenaria (Proite et al. 2007, 2008); is closely related to $A$. duranensis, the most probable A genome donor to cultivated peanut (Seijo et al. 2004); forms fertile hybrids with apparently normal genetic behavior; and is a parent of a well characterized diploid mapping population for the A genome of Arachis (Moretzsohn et al. 2005; Guimarães et al. 2008; Bertioli et al. 2009; Leal-Bertioli et al. 2009).

Several studies have identified genes and promoters that respond during both the susceptible and resistant plantnematode interaction in a number of plant species (Barthels et al. 1997; Goellner et al. 2001; Koltai et al. 2001). Recently, laser capture microdissection (LCM) has been applied for gene expression analysis of the interaction between plant root and parasitic nematodes (root-knot and cyst nematode) (Klink et al. 2009b; Portillo et al. 2009; Barcala et al. 2010). This approach has shown that, within specific pathosystems, different transcripts related to the plant resistance response against particular nematodes can be identified. Transcripts vary according to plant genotype (Klink et al. 2009b, 2010a, b) pathogen isolate (Klink et al. 2009a), host cell type or different points during an interaction time course (Barcala et al. 2010) (Portillo et al. 2009).

In peanut, whilst a relatively large number of ESTs are available both from Meloidogyne species (McCarter et al. 2003; Abad et al. 2008; Roze et al. 2008) and from healthy Arachis plants (Luo et al. 2005b), few studies of the genes expressed during the peanut-nematode interaction has, to our knowledge, been published (Proite et al. 2007).
In a previously published study, a comparative histopathological analysis of susceptible $A$. hypogaea and resistant $A$. stenosperma challenged by $M$. arenaria, showed that the mechanism of resistance in this wild species acted in at least two stages: many less nematodes penetrated the resistant root, and those that did were killed by a hypersensitive reaction (HR) in the plant cells surrounding them (Proite et al. 2008). In addition, ESTs were produced from A. stenosperma roots, both unchallenged roots and roots challenged with $M$. arenaria (Proite et al. 2007).

In this paper, we identified genes differentially expressed between inoculated and non-inoculated roots of the resistant wild peanut species $A$. stenosperma. We selected the three most differentially expressed of these genes for closer analysis in both $A$. stenosperma and in the compatible cultivated peanut $A$. hypogaea.

\section{Results}

\section{Plant Materials and Bioassay}

The reproductive factor (RF) (Oostenbrink 1966) of $M$. arenaria race 1 at $120 \mathrm{DAI}$ in A. hypogaea (cv. IAC-TatuST) was 16.4 , whilst $A$. stenosperma (accession V10309) did not support any nematode multiplication. These results were in accordance with our previous works (Leal-Bertioli et al. 2007; Proite et al. 2008) which characterized the contrasting response of wild and cultivated species challenged with this nematode species. Plant roots were collected at 2, 4, 9 and 16 days after inoculation (DAI) for total RNA extractions based on previous hystopathological assays (Proite et al. 2008) which showed that the responses of A. stenosperma and A. hypogaea inoculated with $M$. arenaria race 1 showed marked differences at these time points.

\section{In Silico Analysis}

In silico analysis of the ESTs [GenBank: EH041934 to EH048197] showed that eight genes were differentially expressed in the inoculated (RM) and non-inoculated (RN) A. stenosperma libraries, according to Fisher test $(P \leq 0.05)$ (Fig. 1 and Table S-1). Four of these genes were upregulated under nematode challenge and had homologies (BLASTx value $\mathrm{E}<1.0 \mathrm{e}^{-10}$ ) to: Auxin-repressed protein ARP1 from A. hypogaea (AsARP), Metallothionein type 3b from A. hypogaea (AsMET3) and two hypothetical proteins from Nicotiana tabacum (AsHPNt) and from Ricinus communis (AsHPRc). Four genes were down-regulated under nematode challenge and showed homology to: Metallothionein type 2 (AsMET2) from A. hypogaea, 
Fig. 1 Number of reads of the eight genes (AsARP; AsMET3; AsHPNt; AsHPRc; AsMET2, AsCKX, AsADH and AsRS) differentially expressed at 2, 6 and 10 DAI in roots of $A$. stenosperma inoculated (RM library) and non-inoculated (RN library) with $M$. arenaria, according to in silico analysis $(P$ $<0.05)$. Percentages correspond to the number of reads for each contig in each library

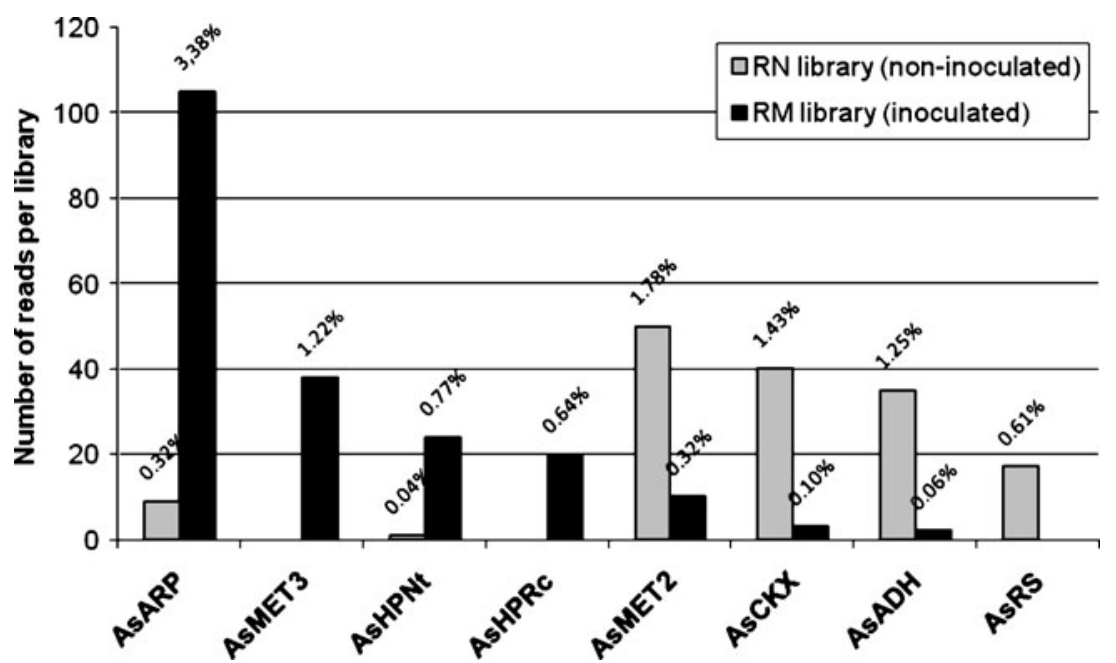

Cytokinin-oxidase from Medicago truncatula (AsCKX), Alcohol dehydrogenase 1 from Pisum sativum (AsADH) and Resveratrol synthase (AsRS) from A. hypogaea (Fig. 1). In addition, 92 clones were exclusively found in the inoculated libraries (RM), 20 of which were related to defense mechanisms, according to the BLASTx analysis $\left(\mathrm{E}<1.0 \mathrm{e}^{-10}\right)$ (Table S-1).

\section{Overall Expression Profiling}

The in silico data allowed the selection of seventy-one ESTs for expression profiling analysis using the following criteria: clones representing the eight genes that were differentially expressed between the two EST libraries; clones that were exclusive to the RM library; or with homology to genes encoding proteins related to plant response to biotic and abiotic stress e.g. heat shock and ROS-responsive proteins, transcription factors (AP2/ EREBP, TAF and GRAS), disease-resistance or PR proteins (Table S-1). For each of the eight genes considered as differentially expressed by in silico analysis, at least three clones representative of the respective contig were included on the membrane. Additionally, four clones were also selected as constitutively expressed genes for internal control. To monitor the expression patterns of this set of 75 selected genes during the first stages of $M$. arenaria challenge to $A$. stenosperma, a time-course experiment was performed by hybridizing macroarrays to cDNA probes corresponding to mRNA from inoculated roots at 2, 4 and 9 DAI and to a control pool (mRNA from a pool of noninoculated roots collected at the same time points).

Among the four putative housekeeping genes selected, $\beta$-tubulin was chosen as internal standardization membrane control because no significant variation of its expression was observed among all the membranes tested (data not shown). Degrees of induction/repression of each gene at specific time-points were calculated based on the ratio of the average relative signal intensities of inoculated samples to those of control samples, using $\beta$-tubulin gene as reference sample. Clones with a ratio above 1.5 fold, or below 0.66 were considered as having significant changes. Scattered plots of the 75 genes (Fig. 2) indicate that mRNA expression profile of $A$. stenosperma changes during the course of the 9 days after inoculation with $M$. arenaria. At 2 DAI, 19 genes (25\%) were significantly up-regulated upon nematode inoculation (Fig. 2), such as uricase (4.5fold) and an ethylene-responsive transcription factor (4.1fold) homologs. Repression of gene expression by nematode inoculation was observed for only 6 genes $(8 \%)$ with four of them showing a strong down regulation: lipocalin (0.41-fold), a plasma membrane protein (0.45-fold), a metallothionein type 2 protein (0.46-fold) and a mannose/ glucose-binding lectin precursor (0.49-fold). The downregulation of Metallothionein type 2 (AsMET2) after nematode inoculation of $A$. stenosperma was also observed in silico (see above). At 4 DAI, there was no remarkable differences in the overall gene expression profile compared to 2 DAI (Fig. 2) except for the following genes: mannose/ glucose-binding lectin precursor (from 0.49 to 6.97 -fold) and lipocalin (from 0.41 to 4.5 -fold). At 9 DAI, the overall gene expression profile showed a remarkable change, as the number of up-regulated genes increased drastically, corresponding to $53 \%$ (40 genes) of all the selected genes (Fig. 2). Among these positively regulated genes at $9 \mathrm{DAI}$, 20 showed an increase of the mRNA level between 1.8-and 2.5-fold (two clones corresponding to AsARP, two AsMET3, two AsHPNt, one AsHPRc and nuclear factor $\mathrm{Y}$, copper-binding protein CUTA, glutathione-S-transferase, ethylene-responsive element-binding protein, lipocalin and others) and six more than 2.5-fold (two clones corresponding to AsARP, two AsHPRc, helix-loop-helix and U-box proteins). Otherwise, repression of gene expression by nematode 

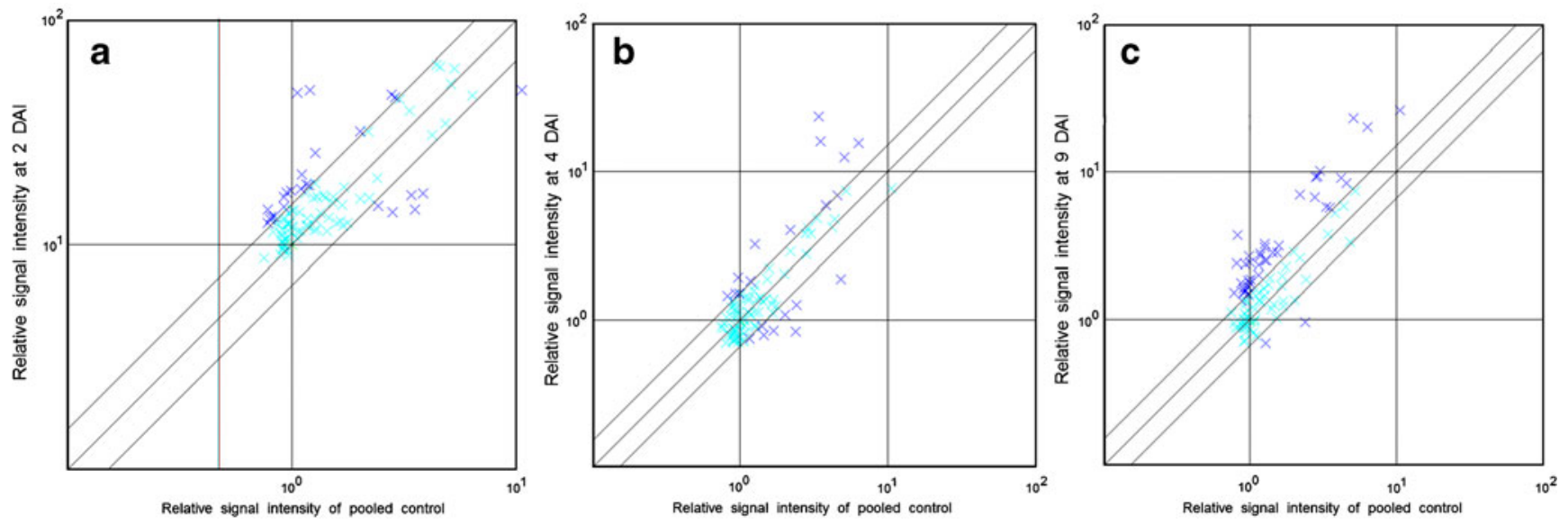

Fig. 2 Scattered plot of cDNA hybridization in macroarray membranes. The plot displays the average relative signal intensity of all spots probed with cDNA from a pool of control samples (x-axis) and

inoculation at 9 DAI was observed for only 2 genes (3\%), corresponding to AsCKX and AsRS. Therefore, six significantly regulated genes at 9 DAI (AsARP, AsHPRc, AsHPNt, AsMET3, AsCKX and AsRS) were also identified as differentially expressed by our in silico analysis.

Comparison of Differentially Expressed Genes in Resistant and Susceptible Arachis spp.

Comparison of the in silico and macroarray data indicated that the two profiles were consistent for most of the 75 clones tested. The three mostly differentially expressed genes in silico that also showed significant changes in expression on macroarrays were selected for further analysis using northernblot in both A. stenosperma and A. hypogaea: AsARP (upregulated with nematode inoculation), and AsMET2 and AsCKX, (down-regulated) (Fig. 3).

\section{Auxin-repressed Protein (ARP)—AsARP}

According to in silico and macroarray analysis, the most differentially expressed gene during the early stages of $M$. arenaria challenge on A. stenosperma roots encoded an Auxin Repressed Protein (ARP) (AsARP) with a strong upregulation in challenged roots (107 reads) compared to nonchallenged (9 reads) (Fig. 1). The up-regulation of AsARP in A. stenosperma inoculated roots was also observed in macroarray hybridizations with a steady increase in expression in all time points and a two-fold increase in hybridization signal between 2 and 9 DAI (Fig. 3). While many genes up-regulated by auxin have been characterized, less is known about those that are down-regulated by auxin, with some of them related to dormancy and some induced by cold, insects, and bacteria (Stafstrom et al. 1998; Hwang et al. 2005; Song et al. 2007; Salvianti et al. 2008). Likewise, northern-blot analysis of total RNA, showed that AsARP was up-regulated inoculated samples collected at 2 (a); 4 (b) and 9 (c) DAI (y-axis). The upper and lower perpendicular lines indicate the position of 1.5 -fold differences in intensity

at 4, 9 and 16 DAI in inoculated roots of the resistant $A$. stenosperma, when compared to non-inoculated (Fig. 4a). In the susceptible A. hypogaea, however, AsARP was downregulated at $16 \mathrm{DAI}$ in inoculated roots when compared to non-inoculated (Fig. 4a).

\section{Metallothionein Type 2 (MET2)-AsMET2}

The second most differentially expressed sequence in this study encoded Metallothionein-like protein type 2 (AsMET2), and was much more frequent in the library from non-inoculated roots of $A$. stenosperma $\mathrm{RN}$ (50 reads) than in $M$. arenaria inoculated roots RM (10 reads) libraries (Fig. 1). The macroarray analysis also showed down regulation of AsMET2 in the inoculated roots of $A$. stenosperma when compared to the control. However, a much earlier response (0.46- and 0.77 -fold at 2 and 4 DAI,

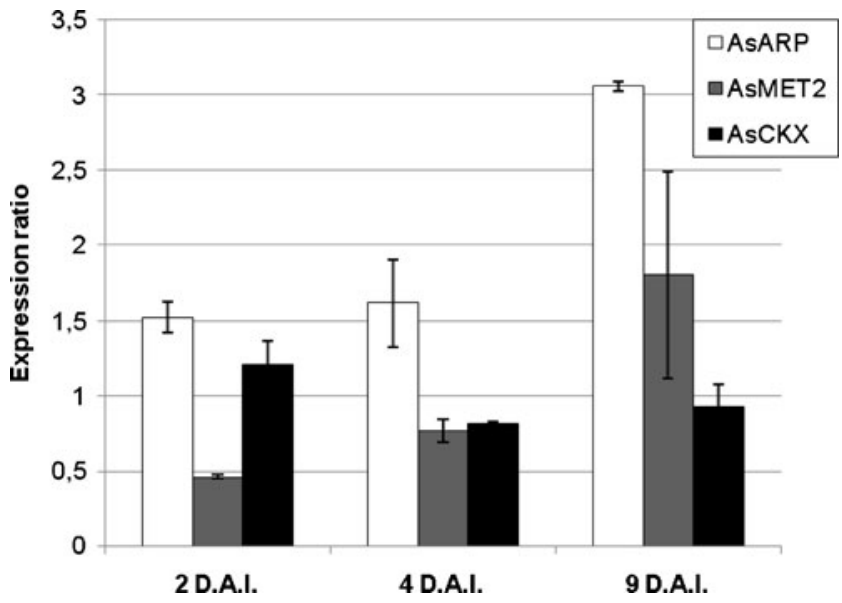

Fig. 3 Macroarray analysis of representative AsARP, AsMET2 and AsCKX clones. Expression ratio (y-axis) was determined as the average relative signal intensity of inoculated to control samples at each indicated time (2, 4 and $9 \mathrm{DAI})$. Bars show the standard error of signal intensity of at least three clones representing the same gene 


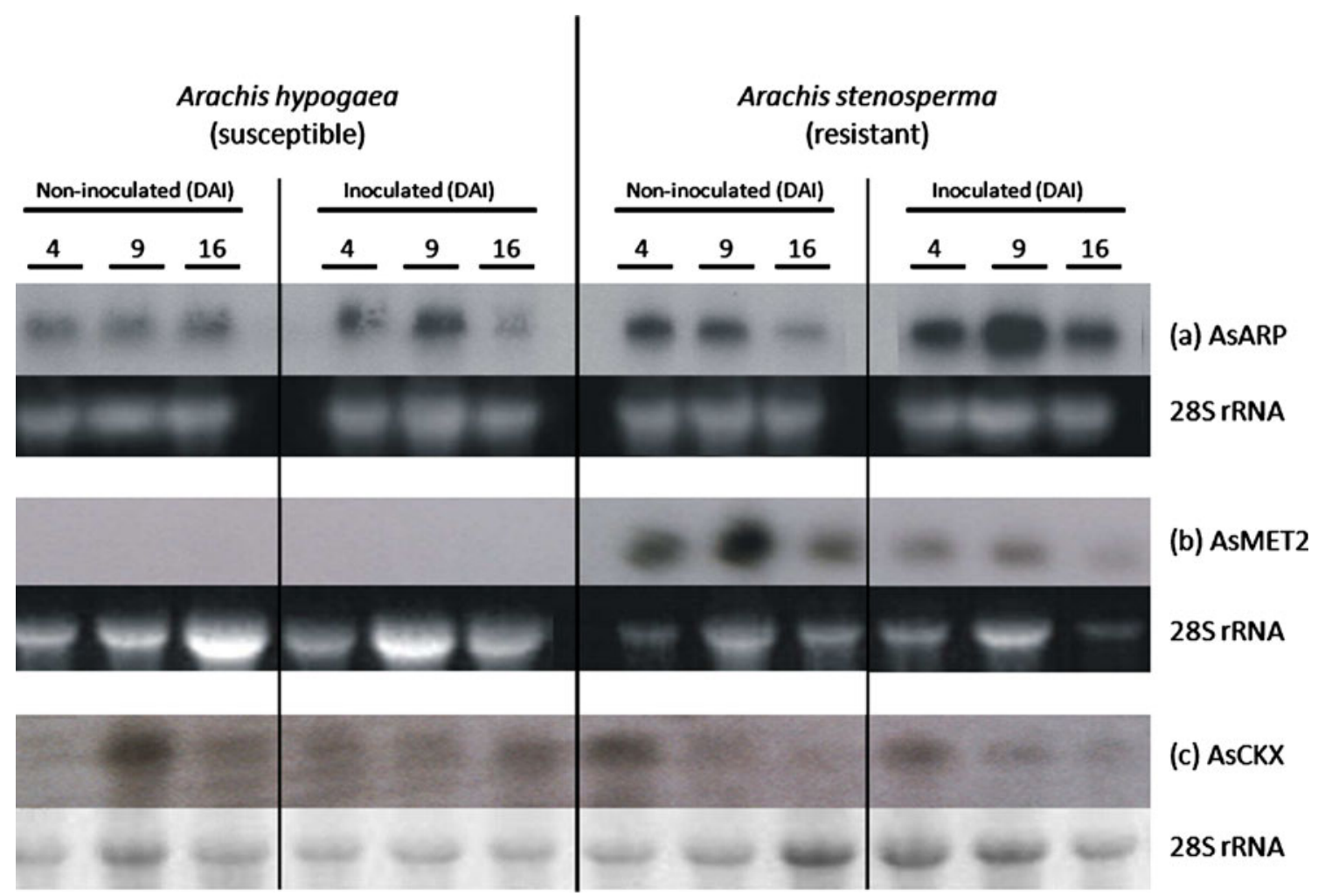

Fig. 4 Northern-blots of total RNA from non-inoculated and inoculated samples of $A$. hypogaea (left) and A. stenosperma (right) at 4, 9 and 16 DAI, hybridized to a representative clone of (a) AsARP;

respectively) was observed followed by an increase of its expression at 9 DAI (1.8-fold; Fig. 3). Nevertheless, the variation in its induction at 9 DAI (Fig. 3) prohibits a strong conclusion regarding its up regulation. Northern-blot analysis showed a striking difference in expression levels of AsMET2 in all times analyzed between the wild resistant species and the susceptible cultivated peanut (Fig. 4b). A noticeable down-regulation of AsMET2 in A. stenosperma roots challenged with $M$. arenaria at 9 and 16 DAI was also observed (Fig. 4b). The occurrence of the hypersensitive response at 9 and $16 \mathrm{DAI}$ in A. stenosperma but not in $A$. hypogaea (Proite et al. 2008) suggests that AsMET2 may have a role in this resistant response.

\section{Cytokinin-oxidase/Desidrogenase (CKX)—AsCKX}

The catabolic enzyme cytokinin oxidase (CKX) plays an important role in controlling cytokinin levels in plant tissues as it catalyzes the irreversible degradation of cytokinins (Brugiere et al. 2003; Ashikari et al. 2005). In A. stenosperma, Cytokinin-oxidase/dehydrogenase (AsCKX) was one of the eight in-silico detected differentially expressed genes between non-inoculated RN (40 reads) and inoculated roots RM (3 reads) (Fig. 1), showing a slight down-regulation especially at 4 DAI in A. stenosperma (b) AsMET2; (c) AsCKX. Total RNA of each sample was electrophoresed on ethidium bromide stained gels for northern blotting

inoculated roots (Fig. 4c). A higher expression of AsCKX is observed in inoculated A. hypogaea roots than in noninoculated at $16 \mathrm{DAI}$, possibly suggesting that cytokinin is being accumulated in the compatible system for the formation of the feeding site.

Likewise, in the macroarray analysis a strong (2,5 fold) down regulation was detected between 2 and 4 DAI and maintained at $9 \mathrm{DAI}$ in inoculated A. stenosperma (Fig. 3)

\section{Discussion}

In agriculture, nematodes can be controlled by crop rotation, nematicides and resistant cultivars. So far, only a single source of resistance against root-knot nematodes is available in commercial cultivars of peanut (Simpson et al. 2003), since pathogens can overcome plant resistance, the investigation of new sources of resistance is desirable.

The most common defense mechanism against root-knot nematodes (Meloidogyne spp.) is the hypersensitive response (HR) where the invading juvenile is not able to induce a feeding site and becomes surrounded and embedded among necrotized cells (Sobczak et al. 2005). This mechanism (HR) has been recently described by our 
group in wild Arachis (A. stenosperma) responding to challenge with $M$. arenaria (Proite et al. 2007, 2008). In this previous study, A. stenosperma accession V10309 and $A$. hypogaea inoculated with $M$. arenaria race 1 showed marked differences in the nematode developmental cycle before 16 DAI. Many fewer nematodes were able to penetrate A. stenosperma roots, and a hypersensitive response was already visible around those that did in by 8 DAI. In contrast, in A. hypogaea, feeding sites were already present at $16 \mathrm{DAI}$. Therefore, to cover key stages of the plant-nematode interaction in both species, in the present study, roots were collected at 2, 4, 9 and 16 DAI for the analysis of gene differential expression by various methods.

The hypersensitive response often forms part of the resistance response of a plant against a challenging pathogen. It is associated with rapid ion fluxes, protein phosphorylation, accumulation of reactive oxygen species (ROS), nitric oxide, salicylic acid, sphingolipids and induction of defense-related genes (Heath 2000) (Mur et al. 2008). A number of studies have shown that the transformation of normal root cells in nematode feeding structures requires complex morphological and physiological changes (Gheysen and Fenoll 2002; Fosu-Nyarko et al. 2009; Portillo et al. 2009) as well as changes in expression patterns of genes including extensins (van der Eycken et al. 1995), glucanases (Niebel et al. 1996; Goellner et al. 2001), cyclins (Niebel et al. 1996; Engler et al. 1999), phytohormones (Goverse et al. 2000) and transcription factors (Barcala et al. 2010; Klink et al. 2010a).

Likewise, some genes were differentially expressed in the response of A. stenosperma to M. arenaria, and were also related to hormonal balance (AsARP and AsCKX) and pathogenesis (AsMET2, AsMET3, AsADH, AsRS) as well as proteins of unknown function (AsHPRc and AsHPNt) (Fig. 1).

Several studies have shown that auxin plays an important role in feeding cell induction by root-knot nematodes, being essential in giant-cell formation (Doyle and Lambert 2003; Mazarei et al. 2007; Barcala et al. 2010). It regulates various growth and developmental processes in plants by controlling the expression of auxin-responsive genes. A number of these genes have been classified as early auxin-response genes (Guilfoyle et al. 1998) with their expression levels increasing within minutes of auxin application, independent of de novo protein synthesis (Walker and Estelle 1998).

However, to date, auxin-repressed protein (ARP) genes and their role in plant growth and development are relatively understudied, with a few homologs found in strawberry (Reddy and Poovaiah 1990), pea (Stafstrom et al. 1998), the tree legume Robinia pseudoacacia (Park and Han 2003), tobacco (Steiner et al. 2003), pepper (Jung and Hwang 2000; Hwang et al. 2005) and pear (Salvianti et al.
2008). So far, these genes have been related to dormancy (Stafstrom et al. 1998) and induction by cold (Hwang et al. 2005), insects (Salvianti et al. 2008) and bacteria (Jung and Hwang 2000).

In this study, the most highly nematode-induced gene in A. stenosperma roots (AsARP; Figs. 1 and 4a) presented 98\% identity, according to BLASTN, to the gene encoding auxin repressed protein in A. hypogaea (EH047263.1). Northern-blot revealed single bands of the same mobility in both A. stenosperma and A. hypogaea. This and the observation that homologs of this gene are present in single copies in the model plants Medicago truncatula, Lotus japonicus, and Arabidopsis thaliana, suggest that AsARP and EH047263.1 most probably represent the same gene in the two different species.

The gene has markedly different behaviors in $A$. stenosperma and A. hypogaea when challenged with nematodes, being strongly induced and repressed respectively (Fig. 4a). In addition, the gene has different levels of expression in non-inoculated roots, being expressed at a higher level in A. stenosperma.

This suggests that in infected $A$. stenosperma, the AsARP was highly expressed due to a failure in gall formation and lack of auxin accumulation. Another legume auxin-repressed ortholog RpARP (Park and Han 2003) has been reported as negatively related to hypocotyls elongation and plays an important role in biological processes that are characteristic under non-growing or stress conditions.

Other ARP encoding genes have also been reported as being up regulated in plant disease resistance responses. For example, in pepper leaves infected with Xanthomonas campestris (Jung and Hwang 2000), in SAR induced coffee leaves (De Nardi et al. 2006), in fungi infected peanut (Luo et al. 2005a) and grapevine leaves (Camps et al. 2010). However, it remains unknown if the expression of ARP forms an integral part of the resistance response of $A$. stenosperma, or is just correlated with it.

Together with auxin, cytokinin plays an essential role in plant morphogenesis, having a profound influence on the formation of roots and shoots and their relative growth, and branching (Brugiere et al. 2003). The catabolic enzyme cytokinin oxidase/dehydrogenase (CKX) plays a major role in controlling cytokinin levels in plant tissues and has been carefully characterized in a number of plants (Brugiere et al. 2003; Aval'baev et al. 2006; Hirose et al. 2007). In most systems, CKX expression is induced by cytokinins (Brugiere et al. 2003) representing a negative feedback system in which the accumulation of cytokinin induces its own catabolism, controlling the levels of the hormone in the cell (Lee et al. 2007). Not surprisingly, cytokinin appears to play a role in the formation of nematode feeding sites, being accumulated during site formation (De Meutter et al. 2001; Bird 2004; Barcala et 
al. 2010). Accordingly, the over-expression of CKX in $L$. japonicus has been shown to reduce the number of galls formed after nematode challenge (Lohar et al. 2004).

As was the case for ARP, expression of CKX contrasts between the resistant $A$. stenosperma and the susceptible $A$. hypogaea. Whilst CKX was down-regulated in A. stenosperma 9 and $16 \mathrm{DAI}$, in A. hypogaea the expression increased (Fig. 4c). This period coincides with the formation of the nematode feeding sites, and suggests a role of this enzyme in the establishment of the plantnematode interaction.

During the incompatible hypersensitive response (HR) there is a significative accumulation of reactive oxygen ROS (Heath 2000), which may directly repel invading pathogens or serve as signaling molecules that activate defense response (Hammond-Kosack and Jones 1996). On the other hand, ROS resulting from biotic and abiotic stresses can cause cellular damage and need to be detoxified (Mittler 2002). Metallothioneins are low molecular (6-7 kD), Cys-rich, metal-binding proteins that have a role in protection against the effects of ROS by acting as antioxidants as they are potent scavengers of hydroxyl radicals (Potenza et al. 2001). In rice, the expression of metallothionein type 2 was down-regulated when cells were treated with oxidative burst (ROS) inducers, indicating that this protein is associated with the hypersensitive response (Wong et al. 2004). Additionally, when metallothionein type 2 levels were increased, the oxidative response diminished and consequently the resistance of these plants to diseases such as bacterial blight and rice blast (Wong et al. 2004). This gene was also found to be down-regulated in alfalfa roots inoculated with $M$. incognita (Potenza et al. 2001).

A gene encoding a metallothionein-like type 2 protein (AsMET2) was the second most differentially expressed gene in the present study, being much more frequent in non-inoculated than in inoculated roots of A. stenosperma. This down regulation in inoculated roots is compatible with the resistant hypersensitive response an accumulation of ROS in A. stenosperma during its response to nematodes (Proite et al. 2007), Furthermore, macroarray analysis showed a very early response of AsMET2, again consistent with the very early appearance of HR. Searches of EST databases showed that $A$. hypogaea does have this gene, ESTs from peanut cotyledon with $98 \%$ identity being identified. Interestingly however, in A. hypogaea, AsMET2 expression was not detected either in the inoculated or noninoculated plants, this highlights a very marked difference in the behavior of this gene between the two species inoculated and not inoculated with nematodes.

The study of the expression profile of the above host genes during the plant-nematode interaction and their further characterization are important steps to understanding the molecular mechanisms involved in the resistant and susceptible responses of peanut and other legumes to nematode challenge.

\section{Methods}

Plant Materials and Bioassays

Arachis stenosperma (accession V10309) and A. hypogaea (cultivar IAC- Tatu -ST) seeds were obtained from the Arachis Germplasm Bank, and maintained at Embrapa Genetic Resources and Biotechnology-Cenargen (BrasíliaDF, Brazil). Ten week old plants of A. stenosperma V10309 and the susceptible cultivated $A$. hypogaea were inoculated with $10,000 M$. arenaria race 1 juveniles $\left(\mathrm{J}_{2}\right)$ (Proite et al. 2008). For gene expression analysis, roots were collected at 2, 4, 9 and 16 days after inoculation (DAI) which correspond to the early stages of the hypersensitive reaction in A. stenosperma, according to Proite and co-workers (Proite et al. 2008). Roots were also collected after the completion of the nematode cycle (120 DAI) and the reproductive factor (RF) analyzed (Oostenbrink 1966). For macroarray and northern-blot analyses, plant material was immediately frozen on liquid nitrogen and total RNA extracted using Trizol reagent (Invitrogen), according to manufacturer's protocol.

\section{In Silico Analysis and FISHER Test}

The EST data previously developed from two cDNA libraries from A. stenosperma inoculated (RM) and noninoculated (RN) roots with $M$. arenaria (Proite et al. 2007) was used for the identification of differentially expressed genes in silico. Fisher's exact test was used to examine the significance of the association between the two variables (inoculated and non-inoculated plants) with a $P \leq 0.05$.

\section{Macroarray Hybridizations}

Seventy-five clones were selected from the A. stenosperma cDNA libraries [GenBank:EH041934 to EH048197] (Proite et al. 2007) (Table S-1). Four clones were included as housekeeping candidate genes for internal control: (i) actin; (ii) glyceraldehyde-3-phosphate dehydrogenase; (iii) $60 \mathrm{~S}$ ribosomal protein and (iv) $\beta$-tubulin (Table S-1). Plasmid DNA was extracted by alkaline-lysis and used as a template for PCR amplification using PT2F2 (GCGCCATTGTGTTGG TACCC) and PT2R2 (CCGCATGCATAAGCTTGCTC) primers. DNA samples $(800 \mathrm{ng}$ ) were spotted twice onto nylon Hybond $\mathrm{N}+$ membranes (GE Healthcare), according to manufacturer's protocol. 
Total RNA from challenge and non-challenged roots of A. stenosperma at 2, 4, and 9 DAI was purified using the Invisorb Spin Plant RNA Mini Kit (Invitek) and reversetranscribed to be used as probes. Reverse transcription reactions were performed with SuperScriptIIRT (Invitrogen), according to the manufacture's protocol, using $10 \mu \mathrm{g}$ of total RNA, and $50 \mu \mathrm{Ci} \alpha\left[{ }^{33} \mathrm{P}\right] \mathrm{dCTP}$. Denatured probe was added to Church and Gilbert buffer (Church and Gilbert 1984) and hybridization was performed overnight at $65^{\circ} \mathrm{C}$. Membranes were washed in $2 \mathrm{XSSC} / 0.1 \%$ SDS at $65^{\circ} \mathrm{C}$ and $42^{\circ} \mathrm{C}$ for $15 \mathrm{~min}$, exposed to ImagingPlate screen for $24 \mathrm{~h}$, and scanned on FLA-3000A image analyzer (FujiFilm). Array Gauge software (FujiFilm) was used to quantify and normalize spot intensities. Standard normalization (based on the intensity signal of a putative housekeeping gene) was adopted for normalizing the difference of hybridization signal intensity intra and between membranes. The radioactive signal intensity of the duplicated spots was averaged prior further analysis.

\section{Northern-blots}

Northern-blots were conducted using $10 \mu \mathrm{g}$ of total RNA per sample, according to the membrane manufacturer's instructions (Hybond-N; GE Healthcare). Representative clones of the differentially expressed genes previously identified by Fisher test and macroarrays were used as probes (AsARP, AsCKX and AsMET2). Probes were labeled with $\alpha\left[{ }^{32} \mathrm{P}\right] \mathrm{dCTP}$ using random priming, according to the manufacturer's instructions (Ready-to-Go; GE Healthcare) and washes performed in $2 \mathrm{XSSC} / 0.1 \%$ SDS at $65^{\circ} \mathrm{C}$ for $15 \mathrm{~min}$. Membranes were exposed to X-ray film (Kodak).

Acknowledgements The authors gratefully acknowledge The Challenge Program Generation, Tropical Legume Improvement (TL1), CNPq, FAP-DF and host institutions for funding this research. The authors also wish to thank Dr. Regina D.G. Carneiro (Embrapa Recursos Genéticos e Biotecnologia, Brazil) for providing nematodes.

\section{References}

Abad P, Gouzy J, Aury JM, Castagnone-Sereno P, Danchin EGJ, Deleury E, Perfus-Barbeoch L, Anthouard V, Artiguenave F, Blok VC et al (2008) Genome sequence of the metazoan plantparasitic nematode Meloidogyne incognita. Nat Biotechnol 26:909-915

Ashikari M, Sakakibara H, Lin SY, Yamamoto T, Takashi T, Nishimura A, Angeles ER, Qian Q, Kitano H, Matsuoka M (2005) Cytokinin oxidase regulates rice grain production. Science 309:741-745

Aval'baev AM, Yuldashev RA, Vysotskaya LB, Shakirova FM (2006) Regulation of gene expression and activity of cytokinin oxidase in the roots of wheat seedlings by 24-Epibrassinolide. Dokl Biochem Biophys 410:317-319

Barcala M, Garcia A, Cabrera J, Casson S, Lindsey K, Favery B, Garcia-Casado G, Solano R, Fenoll C, Escobar C (2010) Early transcriptomic events in microdissected Arabidopsis nematodeinduced giant cells. Plant J 61:698-712

Barthels N, van der Lee FM, Klap J, Goddijn OJM, Karimi M, Puzio P, Grundler FMW, Ohl SA, Lindsey K, Robertson L et al (1997) Regulatory sequences of Arabidopsis drive reporter gene expression in nematode feeding structures. Plant Cell 9:2119-2134

Bertioli DJ, Moretzsohn MC, Madsen LH, Sandal N, Leal-Bertioli SCM, Guimaraes PM, Hougaard BK, Fredslund J, Schauser L, Nielsen AM et al (2009) An analysis of synteny of Arachis with Lotus and Medicago sheds new light on the structure, stability and evolution of legume genomes. BMC Genomics 10

Bird DM (2004) Signaling between nematodes and plants. Curr Opin Plant Biol 7:372-376

Brugiere N, Jiao SP, Hantke S, Zinselmeier C, Roessler JA, Niu XM, Jones RJ, Habben JE (2003) Cytokinin oxidase gene expression in maize is localized to the vasculature, and is induced by cytokinins, abscisic acid, and abiotic stress. Plant Physiol 132:1228-1240

Camps C, Kappel C, Lecomte P, Leon C, Gomes E, Coutos-Thevenot P, Delrot S (2010) A transcriptomic study of grapevine (Vitis vinifera $\mathrm{cv}$. Cabernet-Sauvignon) interaction with the vascular ascomycete fungus Eutypa lata. J Exp Bot 61:1719-1737

Church GM, Gilbert W (1984) Genomic sequencing. Proc Natl Acad Sci USA 81:1991-1995

Church G, Simpson C, Burow M, Paterson A, Starr J (2000) Use of RFLP markers for identification of individuals homozygous for resistance to Meloidogyne arenaria in peanut. Nematology 2:575-580

De Meutter J, Vanholme B, Bauw G, Tytgat T, Gheysen G, Gheysen G (2001) Preparation and sequencing of secreted proteins from the pharyngeal glands of the plant parasitic nematode Heterodera schachtii. Mol Plant Pathol 2:297-301

De Nardi B, Dreos R, Del Terra L, Martellossi C, Asquini E, Tornincasa P, Gasperini D, Pacchioni B, Raihinavelu R, Pallavicini A, Graziosi G (2006) Differential responses of Coffea arabica L. leaves and roots to chemically induced systemic acquired resistance. Genome 49:1594-1605

Dickson DW, Waele DD (2005) Nematode parasites of peanut nematode parasites of cotton and other tropical fibre crops. In: Luc M, Sikora RA, Bridge J (eds) Plant parasitic nematodes in tropical and subtropical agriculture, 2nd edn. CAB International, Wallingford

Doyle EA, Lambert KN (2003) Meloidogyne javanica chorismate mutase 1 alters plant cell development. Mol Plant-Microb Interact 16:123-131

Engler JD, De Vleesschauwer V, Burssens S, Celenza JL, Inze D, Van Montagu M, Engler G, Gheysen G (1999) Molecular markers and cell cycle inhibitors show the importance of cell cycle progression in nematode-induced galls and syncytia. Plant Cell 11:793-807

FAOSTAT (2006) http://faostatfaoorg/site/567/defaultaspx

Fosu-Nyarko J, Jones MGK, Wang ZH (2009) Functional characterization of transcripts expressed in early-stage Meloidogyne javanica-induced giant cells isolated by laser microdissection. Mol Plant Pathol 10:237-248

Gheysen G, Fenoll C (2002) Gene expression in nematode feeding sites. Annu Rev Phytopathol 40:191-219

Goellner M, Wang XH, Davis EL (2001) Endo-beta-1, 4-glucanase expression in compatible plant-nematode interactions. Plant Cell 13:2241-2255 
Goverse A, Engler JD, Verhees J, van der Krol S, Helder J, Gheysen G (2000) Cell cycle activation by plant parasitic nematodes. Plant Mol Biol 43:747-761

Guilfoyle T, Hagen G, Ulmasov T, Murfett J (1998) How does auxin turn on genes? Plant Physiol 118:341-347

Guimarães PM, Garsmeur O, Proite K, Leal-Bertioli SCM, Seijo G, Chaine C, Bertioli DJ, D'Hont A (2008) BAC libraries construction from the ancestral diploid genomes of the allotetraploid cultivated peanut. BMC Plant Biology 8

Hammond-Kosack KE, Jones JDG (1996) Resistance gene-dependent plant defense responses. Plant Cell 8:1773-1791

Heath MC (2000) Nonhost resistance and nonspecific plant defenses. Curr Opin Plant Biol 3:315-319

Hirose N, Kentaro T, Kuroha T, Kamada-Nobusada T, Hayashi H, Sakakibara H (2007) Regulation of cytokinin biosynthesis, compartmentalization and translocation. J Exp Bot 1-9

Hwang EW, Kim KA, Park SC, Jeong MJ, Byun MO, Kwon HB (2005) Expression profiles of hot pepper (Capsicum annuиm) genes under cold stress conditions. J Biosci 30:657-667

Jung HW, Hwang BK (2000) Isolation, partial sequencing, and expression of pathogenesis-related cDNA genes from pepper leaves infected by Xanthomonas campestris pv. vesicatoria. Mol Plant-Microb Interact 13:136-142

Kaloshian I, Lawn D, Williamson VM, Westerdahl B, Miyao G (1996) Resistance-breaking nematodes identified in California tomatoes. Calif Agric 50:18-19

Klink VP, Hosseini P, MacDonald MH, Alkharouf NW, Matthews BF (2009a) Population-specific gene expression in the plant pathogenic nematode Heterodera glycines exists prior to infection and during the onset of a resistant or susceptible reaction in the roots of the Glycine max genotype Peking. BMC Genomics 10

Klink VP, Hosseini P, Matsye P, Alkharouf NW, Matthews BF (2009b) A gene expression analysis of syncytia laser microdissected from the roots of the Glycine max (soybean) genotype PI 548402 (Peking) undergoing a resistant reaction after infection by Heterodera glycines (soybean cyst nematode). Plant Mol Biol 71:525-567

Klink VP, Hosseini P, Matsye PD, Alkharouf NW, Matthews BF (2010a) Syncytium gene expression in Glycine max([PI 88788]) roots undergoing a resistant reaction to the parasitic nematode Heterodera glycines. Plant Physiol Biochem 48:176-193

Klink VP, Overall CC, Alkharouf NW, MacDonald MH, Matthews BF (2010b) Microarray detection call methodology as a means to identify and compare transcripts expressed within syncytial cells from soybean (Glycine max) roots undergoing resistant and susceptible reactions to the soybean cyst nematode (Heterodera glycines). J Biomed Biotechnol

Koltai H, Dhandaydham M, Opperman C, Thomas J, Bird D (2001) Overlapping plant signal transduction pathways induced by a parasitic nematode and a rhizobial endosymbiont. Mol PlantMicrob Interact 14:1168-1177

Leal-Bertioli SCM, Guimaraes PM, Bertioli DJ (2007) Targeting and genotyping RGAs in a mapping population of the AA genome of wild Arachis. Crop Breed Appl Biotechnol 7:179-185

Leal-Bertioli SCM, Jose ACVF, Alves-Freitas DMT, Moretzsohn MC, Guimaraes PM, Nielen S, Vidigal BS, Pereira RW, Pike J, Favero AP et al (2009) Identification of candidate genome regions controlling disease resistance in Arachis. BMC Plant Biol 9:112

Lee Y, Kim MW, Kim SH (2007) Cell type identity in Arabidopsis roots is altered by both ascorbic acid-induced changes in the redox environment and the resultant endogenous auxin response. J Plant Biol 50:484-489

Lohar DP, Schaff JE, Laskey JG, Kieber JJ, Bilyeu KD, Bird DM (2004) Cytokinins play opposite roles in lateral root formation, and nematode and Rhizobial symbioses. Plant J 38:203-214

Luo M, Dang P, Bausher MG, Holbrook CC, Lee RD, Lynch RE, Guo BZ (2005a) Identification of transcripts involved in resistance responses to leaf spot disease caused by Cercosporidium personatum in peanut (Arachis hypogaea). Phytopathology 95:381-387

Luo M, Dang P, Guo BZ, He G, Holbrook CC, Bausher MG, Lee RD (2005b) Generation of expressed sequence tags (ESTs) for gene discovery and marker development in cultivated peanut. Crop Sci 45:346-353

Mazarei M, Elling AA, Maier TR, Puthoff DP, Baum TJ (2007) GmEREBP1 is a transcription factor activating defense genes in soybean and Arabidopsis. Mol Plant-Microb Interact 20:107-119

McCarter JP, Mitreva MD, Martin J, Dante M, Wylie T, Rao U, Pape D, Bowers Y, Theising B, Murphy CV et al (2003) Analysis and functional classification of transcripts from the nematode Meloidogyne incognita. GenomeBiology 4

Mittler R (2002) Oxidative stress, antioxidants and stress tolerance. Trends Plant Sci 7:405-410

Moretzsohn MC, Leoi L, Proite K, Guimaraes PM, Leal-Bertioli SCM, Gimenes MA, Martins WS, Valls JFM, Grattapaglia D, Bertioli DJ (2005) A microsatellite-based, gene-rich linkage map for the AA genome of Arachis (Fabaceae). Theor Appl Genet 111:1060-1071

Mur LAJ, Kenton P, Lloyd AJ, Ougham H, Prats E (2008) The hypersensitive response; the centenary is upon us but how much do we know? J Exp Bot 59:501-520

Nagy ED, Chu Y, Guo Y, Khanal S, Tang S, Li Y, Dong WB, Timper P, Taylor C, Ozias-Akins P et al (2010) Recombination is suppressed in an alien introgression on chromosome $5 \mathrm{~A}$ of peanut harboring Rma, a dominant root-knot nematode resistance gene. Mol Breed, in press

Niebel A, de Almeida EJ, Hemerly A, Ferreira P, Inzé D, Van Montagu M, Gheysen G (1996) Induction of cdc2a and cyc1At expression in Arabidopsis thaliana during early phases of nematode-induced feeding cell formation. Plant J 10:1037-1043

Oostenbrink M (1966) Major characteristics of the relation between nematodes and plants. Med Landbouwhogeschool Wageningen 66:1-46

Park S, Han KH (2003) An auxin-repressed gene (RpARP) from black locust (Robinia pseudoacacia) is posttranscriptionally regulated and negatively associated with shoot elongation. Tree Physiol 23:815-823

Portillo M, Lindsey K, Casson S, Garcia-Casado G, Solano R, Fenoll C, Escobar C (2009) Isolation of RNA from laser-capturemicrodissected giant cells at early differentiation stages suitable for differential transcriptome analysis. Mol Plant Pathol 10:523-535

Potenza C, Thomas SH, Sengupta-Gopalan C (2001) Genes induced during early response to Meloidogyne incognita in roots of resistant and susceptible alfalfa cultivars. Plant Sci 161:289-299

Proite K, Leal-Bertioli SCM, Bertioli DJ, Moretzsohn MC, da Silva FR, Martins NF, Guimaraes PM (2007) ESTs from a wild Arachis species for gene discovery and marker development. BMC Plant Biol 7

Proite K, Carneiro R, Falcao R, Gomes A, Leal-Bertioli S, Guimaraes P, Bertioli D (2008) Post-infection development and histopathology of Meloidogyne arenaria race 1 on Arachis spp. Plant Pathol 57:974980

Reddy ASN, Poovaiah BW (1990) Molecular cloning and sequencing of a cDNA for an auxin-repressed mRNA: correlation between fruit growth and repression of the auxin-regulated gene. Plant Mol Biol 14:127-136

Roze E, Hanse B, Mitreva M, Vanholme B, Bakker J, Smant G (2008) Mining the secretome of the root-knot nematode Meloidogyne chitwoodi for candidate parasitism genes. Mol Plant Pathol 9:1-10

Salvianti F, Bettini PP, Giordani E, Sacchetti P, Bellini E, Buiatti M (2008) Identification by suppression subtractive hybridization of genes expressed in pear (Pyrus spp.) upon infestation with Cacopsylla pyri (Homoptera:Psyllidae). J Plant Physiol 165:1808 1816 
Seijo JG, Lavia GI, Fernandez A, Krapovickas A, Ducasse D, Moscone EA (2004) Physical mapping of the 5S and 18S-25S rRNA genes by fish as evidence that Arachis duranensis and A. ipaensis are the wild diploid progenitors of A. hypogaea (Leguminosae). Am J Bot 91:1294-1303

Simpson CE (2001) Use of wild Arachis species/introgression of genes into Arachis hypogaea. Peanut Sci 28:114-116

Simpson CE, Starr JL, Church GT, Burow MD, Paterson AH (2003) Registration of 'NemaTAM' peanut. Crop Sci 43:1561-1561

Sobczak M, Avrova A, Jupowicz J, Phillips MS, Ernst K, Kumar A (2005) Characterization of susceptibility and resistance responses to potato cyst nematode (Globodera spp.) infection of tomato lines in the absence and presence of the broad-spectrum nematode resistance Hero gene. Mol Plant-Microb Interact 18:158-168

Song YJ, Joo JH, Ryu HY, Lee JS, Bae YS, Nam KH (2007) Reactive oxygen species mediate IAA-induced ethylene production in mungbean (Vigna radiata L) hypocotyls. J Plant Biol 50:18-23

Stafstrom JP, Ripley BD, Devitt ML, Drake B (1998) Dormancyassociated gene expression in pea axillary buds. Planta 205:547-552
Stalker HT (1997) Peanut (Arachis hypogaea L). Field Crops Res 53:205-217

Starr JL, Morgan ER, Simpson CE (2002) Management of the peanut root-knot nematode, Meloidogyne arenaria, with host resistance. Online Plant Health Progress

Steiner C, Bauerb J, Amrheinc N, Buchera M (2003) Two novel genes are differentially expressed during early germination of the male gametophyte of Nicotiana tabacum. Biochim Biophys Acta 1625:123-133

van der Eycken W, de Almeida J, Inzé D, Montagu MV, Gheysen G (1995) A molecular study of root-knot nematode-induced feeding sites. Plant J 9:45-54

Walker L, Estelle M (1998) Molecular mechanisms of auxin action. Curr Opin Plant Biol 1:434-439

Wittwer S (1981) The 20 crops that stand between man and starvation. Farm Chem 144:17-28

Wong HL, Sakamoto T, Kawasaki T, Umemura K, Shimamoto K (2004) Down-regulation of metallothionein, a reactive oxygen scavenger, by the small GTPase OsRac1 in rice. Plant Physiol 135:1447-1456 